\title{
KUALITAS PELAYANAN PEMBINAAN LEMBAGA PENANGGULANGAN BENCANA TERHADAP KEPUTUSAN SATUAN PENDIDIKAN DALAM MENGGUNAKAN JASA KONSELING PADA MUHAMMADIYAH DISASTER MANAGEMENT CENTER (MDMC) KABUPATEN PAMEKASAN ***)
}

\author{
Fajar Surahman ${ }^{1}$, Hendri Masduki ${ }^{2}$ \\ Mahasiswa Program Doktor Universitas Muhammadiyah Malang ${ }^{1}$ \\ Email: soerahman.fajar@gmail.com \\ Direktur Muhammadiyah Disaster Management Center (MDMC) Pamekasan² \\ Email: mdmc.pamekasan1@gmail.com
}

\begin{abstract}
The context of the problem in this study about "Quality of disaster management counseling service for education unit toward decision to use counseling service of Muhammadiyah Disaster Management Center (MDMC) Pamekasan Regency". The result of this research by using multiple linear analyzing show that quality of counseling service for education unit that consist of Reliability $\mathrm{X}_{1}$, Responsiveness $\mathrm{X}_{2}$, Assurance $\mathrm{X}_{3}$, Empaty $\mathrm{X}_{4}$, dan Tangible $\mathrm{X}_{5}$ has effect toward decision of education unit in using counseling service of Muhammadiyah Disaster Management Center (MDMC) Pamekasan Regency.
\end{abstract}

Keywords: Quality of Disaster Management Counseling Service for Education Unit, Decision to Use Counseling Service of Muhammadiyah Disaster Management Center (MDMC) Pamekasan Regency

\begin{abstract}
Abstrak: Konteks permasalahan dalam penelitian ini tentang "Kualitas Pelayanan Jasa Pembinaan Penanggulangan Bencana Satuan Pendidikan Terhadap Keputusan Menggunakan Jasa Konseling Pada Muhammadiyah Disaster Management Center (MDMC) Kabupaten Pamekasan”. Hasil perhitungan dengan menggunakan analisa linear berganda menunjukkan bahwa Kualitas Pelayanan Pembinaan Penanggulangan Bencana Satuan Pendidikan yang terdiri dari Reliability $\mathrm{X}_{1}$, Responsiveness $\mathrm{X}_{2}$, Assurance $\mathrm{X}_{3}$, Empaty $\mathrm{X}_{4}$, dan Tangible $\mathrm{X}_{5}$ mempunyai pengaruh terhadap Keputusan Satuan Pendidikan dalam menggunakan jasa konseling pada Muhammadiyah Disaster Management Center (MDMC) Kabupaten Pamekasan.
\end{abstract}

Kata Kunci: Kualitas Pelayanan Pembinaan Penanggulangan Bencana Satuan Pendidikan; Keputusan Menggunakan Jasa Konseling; Muhammadiyah Disaster Management Center (MDMC) Kabupaten Pamekasan.

***) Karya Ilmiah Hasil Penelitian ini di Presentasikan dalam kegiatan "Call For Paper The $1^{\text {st }}$ International Conference on Islamic Thought (ICIT)" yang diselenggarakan oleh Institut Agama Islam (IAI) Al-Khairat Pamekasan pada Tanggal 18 Januari 2020. Keynote Speaker's (1) Prof. Dr. Hamidullah Marazzi, Ph.D. Hah-i-Hamadan Institut of Islamic Studies India; (2) Prof. Datin. Dr. Raihanan Binti $\mathrm{Hj}$. Abdullah. University of Malaya Malaysia; (3) Dr. Haji Nurarfan Bin Haji. Rector of Unissa Brunei Darussalam; (4) Dr. Tuan Haji Toifur. Direktur Dewan Wakaf Singapore; (5) Dr. Ahsanul Qosasi. Ketua Badan Pemeriksa Keuangan (BPK) Pusat Republik Indonesia. 


\section{PENDAHULUAN}

Kualitas pelayanan dalam suatu organisasi dan atau lembaga seringkali dipahami sebagai suatu keadaan yang lebih baik dilakukan melalui pembenahan sistem dan prosedur dalam organisasi dan atau lembaga. Perspektif TQM (Total Quality Management) memberikan batasan bahwa kualitas tidak hanya ditekankan pada aspek hasil dalam suatu organisasi dan atau lembaga, namun pada aspek lain juga meliputi proses, lingkungan dan manusia yang ada dalam organisasi dan atau lembaga itu sendiri (Tjiptono, 2006).

Pelayanan adalah proses pemenuhan kebutuhan melalui aktivitas orang lain (Moenir, 2002). Zeithaml dalam Umar (2002) mengemukaan 5 (lima) dimensi dalam menentukan kualitas jasa yaitu (1) Reliability, yaitu kemamampuan untuk memberikan pelayanan yang sesuai dengan janji yang ditawarkan; (2) Responsiveness, yaitu respon atau kesigapan karyawan dalam membantu pelanggan dan memberikan pelayanan yang tepat, cepat dan tanggap yang meliputi: kesigapan karyawan dalam melayani pelanggan, kecepatan karyawan dalam menangani transaksi, dan penanganan keluhan pelanggan; (3) Assurance, meliputi kemampuan karyawan atas pengetahuan terhadap produk secara tepat, kualitas keramahtamahan, keterampilan dalam memberikan informasi, kemampuan dalam memberikan keamanan di dalam memanfaatkan jasa yang ditawarkan, dan kemampuan dalam menanamkan kepercayaan pelanggan terhadap organisasi dan atau lembaga. Dimensi kepastian atau jaminan ini merupakan hubungan dari dimensi yaitu Pertama, Kompetensi, artinya keterampilan danpengetahuan yang dimiliki oleh para karyawan untuk melakukan pelayanan; Kedua, Kesopanan, yang meliputi keramahan, perhatian, dan sikap para karyawan; Ketiga, Kredibilitas, meliputi hal-hal yang berhubungan dengan kepercayaan kepada organisasi dan atau lembaga, seperti reputasi, prestasi dan sebagainya. (4) Empaty, yaitu perhatian secara individual yang diberikan organisasi dan atau lembaga kepada pelanggan seperti kemudahan untuk menghubungi organisasi dan atau lembaga, kemampuan karyawan untuk berkomunikasi dengan pelanggan, dan usaha organisasi dan atau lembaga untuk memahami keinginan dan kebutuhan pelanggan. Dimensi Empaty ini merupakan penggabungan dari dimensi Akses, meliputi kemudahan untuk memanfaatkan jasa yang ditawarkan oleh organisasi dan atau lembaga yaitu Pertama, Komunikasi, 
merupakan kemampuan melakukan komunikasi untuk menyampaikan informasi kepada pelanggan atau memperoleh masukan dari pelanggan; Kedua, Pemahaman pada pelanggan, meliputi usaha untuk mengetahui dan memahami kebutuhan dan keinginan pelanggan; dan (5) Tangible, meliputi penampilan fasilitas fisik seperti gedung dan ruangan, tersedianya tempat parkir, kebersihan, ketrampilan, kerapian dan kenyamanan ruangan, kelengkapan peralatan komunikasi dan penampilan karyawan.

Kualitas Pelayanan pada suatu organisasi dan atau lembaga merupakan aspek penting yang menjadi penentu utama terhadap keputusan masyarakat dan atau konsumen penerima manfaat dalam menggunakan produk jasa suatu layanan yang ditawarkan oleh organisasi dan atau lembaga.

Nugroho (2010) menyatakan bahwa Keputusan konsumen untuk menetapkan pilihan terhadap suatu produk dan pilihan-pilihan jasa dapat berubah secara terus-menerus. Setelah mendapatkan informasi dan merancang sejumlah pertimbangan dari produk yang tersedia, konsumen siap untuk membuat suatu keputusan. Pengambilan keputusan yang dilakukan oleh masyarakat dan atau konsumen pada dasarnya merupakan proses pemecahan masalah (Kotler, 2004).

Menurut Basu Swasta (2003) kaitannya dengan jasa pelayanan yang ditawarkan organisasi dan atau lembaga, setidaknya terdapat 7 (tujuh) faktor penentu keputusan suatu masyarakat dan atau konsumen dalam memilih suatu produk jasa yaitu Pertama, Kebudayaan; Kedua, Kelas Sosial; Ketiga, Keluarga; Keempat, Pengalaman; Kelima, Kepribadian; Keenam, Sikap dan Kepercayaan; dan Ketujuh, Konsep Diri. Menurut Kotler (2000) bahwa suatu masyarakat dan atau konsumen memilih suatu produk dan atau pelayanan suatu jasa di dasarkan pada beberapa tahapan yaitu (1) Pengenalan Masalah; (2) Pencarian Informasi; (3) Evaluasi alternatif; (4) Keputusan menggunakan suatu jasa; dan (5) Tingkah laku pasca menggunakan.

Berangkat dari pemikiran di atas, dalam hal ini peneliti mempunyai ketertarikan untuk mengangkat konteks permasalahan dengan judul "Kualitas Pelayanan Pembinaan Penanggulangan Bencana Satuan Pendidikan Terhadap Keputusan Menggunakan Jasa Konseling Pada Muhammadiyah Disaster Management Center (MDMC) Kabupaten Pamekasan”. 


\section{METODE PENELITIAN}

Penelitian ini termasuk penelitian lapangan (field reasearch) dengan menggunakan metode survei. Sedangkan pendekatan analisis yang digunakan dalam penelitian ini adalah pendekatan kuantitatif. Metode survei dalam suatu proses penelitian menurut Murti dan Salamah (dalam Sugiyono 2011) merupakan suatu penelitian yang mengambil sampel dari suatu waktu tertentu dari suatu populasi dengan menggunakan tehnik skedul kuesioner (angket) sebagai alat (instrumen) pengumpulan data pokok. Populasi dalam penelitian ini adalah satuan pendidikan dan atau sekolah yang menggunakan jasa Pembinaan Pelayanan Konseling pada Muhammadiyah Disaster Management Center (MDMC) Kabupaten Pamekasan.

Guna untuk mengetahui pengaruh Kualitas Pelayanan Pembinaan Penanggulagan bencana (X) terhadap Keputusan Satuan Pendidikan dalam menggunakan jasa konseling (Y) Pada Muhammadiyah Disaster Management Center (MDMC) Kabupaten Pamekasan dalam hal ini menggunakan analisis regresi linier berganda (Sugiyono, 2011) dengan menggunakan alat bantu software SPSS for windows 17.00 sebagaimana rumus berikut:

$Y=a+b_{1} X_{1}+b_{2 X_{2}}+b_{3 X_{3}}+b_{4} X_{4}+b_{5} X_{5}$
Dimana :

$$
\begin{array}{ll}
\mathrm{Y} & =\text { dependen variable } \\
\mathrm{a} & =\text { konstanta } \\
\mathrm{b}_{1}, \mathrm{~b}_{2}, \mathrm{~b}_{3}, \mathrm{~b}_{4}, \mathrm{~b}_{5} & =\text { koefisien regresi } \\
\mathrm{n} & =\text { sampel } \\
\mathrm{x}_{1}, \mathrm{x}_{2}, \mathrm{x}_{3}, \mathrm{x}_{4}, \mathrm{x}_{5} & =\text { independen variable } \\
\text { Guna untuk } & \text { mengetahui tingkat }
\end{array}
$$
signifikansi pengaruh variabel $\mathrm{X}$ terhadap Y maka perlu adanya uji hipotesis sebagai berikut:

1. Hipotesis Simultan (Uji F)

Uji F (F_tes) dilakukan untuk menguji taraf signifikansi regresi secara keseluruhan (Simultan) dengan rumus sebagai berikut :

$$
F=\frac{R^{2} / k}{\left(1-R^{2}\right)-(N-k-1)}
$$

Dimana :

$$
\begin{aligned}
\mathrm{R}^{2} & =\text { Koefisien determinasi } \\
\mathrm{k} & =\text { Banyaknya variabel bebas } \\
\mathrm{n} & =\text { Banyaknya observasi } \\
\mathrm{F} & =\text { Nilai } \mathrm{F}_{\text {_hitung }} \text { yang } \\
& \text { selanjutnya dibandingkan } \\
& \text { dengan } \mathrm{F}_{-} \text {tabel }
\end{aligned}
$$

Jika $\mathrm{F}_{\text {_hitung }}$ lebih besar dari $\mathrm{F}_{\text {_tabel, }}$, maka persamaan tersebut secara simultan (bersama-sama) adalah signifikan. Artinya variabel $\mathrm{X}$ berpengaruh signifikan terhadap variabel $\mathrm{Y}$, dengan tingkat signifikansi $95 \%(\alpha=5 \%)$.

\section{Hipotesis Parsial (Uji t)}

Uji t (t_tes) dilakukan untuk menguji taraf signifikansi regresi secara Sendiri- 
sendiri (Parsial) dengan rumus sebagai berikut:

$$
t=\frac{b}{S_{b}}
$$

Dimana :

$$
\begin{aligned}
\mathrm{b} & =\text { Koefisien regresi } \\
\mathrm{S}_{\mathrm{b}} & =\text { Standar deviasi Variabel } \mathrm{X} \\
\mathrm{t} & =\text { Uji hipotesis }
\end{aligned}
$$

Jika $\mathrm{t}$ hitung $>\mathrm{t}$ tabel maka ada pengaruh antara variabel bebas terhadap variabel terikat. Jika $t$ hitung $<\mathrm{t}$ tabel maka tidak ada pengaruh antara variabel bebas terhadap variabel terikat. Berarti variabel bebas kurang dapat menjelaskan variabel terikatnya dan sebaliknya bila $t$ hitung $>t$ tabel maka hipotesis nol $\left(\mathrm{H}_{0}\right)$ di tolak, hipotesis alternatif atau hipotesis kerja $\left(\mathrm{H}_{1}\right)$ diterima. Dengan demikian dapat dikatakan bahwa variabel bebas mampu menjelaskan variabel terikatnya.

\section{PEMBAHASAN}

\section{MDMC (Muhammadiyah Disaster} Management Center) adalah Lembaga Penanggulangan Bencana (LBB) Muhammadiyah sebagai unsur pembantu pimpinan Muhammadiyah dalam proses penanggulangan bencana serta revitalisasi paska bencana sebagai bentuk Dakwah Amar Ma"ruf Nahi

\section{Munkar.}

Pendirian Lembaga Penanggulangan Bencana (LBB) pada tubuh Perserikatan
Muhammadiyah yang selanjutnya disebut MDMC (Muhammadiyah Disaster Management Center) awalnya dibentuk pada tahun 2007 sebagai Badan Penanggulangan Bencana pada Muktamar yang dilaksanakan di Yogyakarta pada tahun 2010 kemudian disahkan menjadi Lembaga Penanggulangan Bencana. Tugas utama MDMC (Muhammadiyah Disaster Management Center) adalah mengkoordinasi sumberdaya Muhammadiyah dalam proses penanggulangan bencana.

Gerakan MDMC (Muhammadiyah Disaster Management Center) tidak hanya terbatas pada penanggulangan bencana semata, melainkan juga pada mitigasi, kesiap siagaan, tanggap darurat dan juga rehabilitasi pasca bencana berbasis dakwah pendampingan dan pemberdayaan sosial (Social development). MDMC (Muhammadiyah Disaster Management Center) menggunakan kode etik kemanusiaan internasional dan juga piadam kemanusiaan internasional dalam proses penanggulangan dan penanggulangan bencana. MDMC (Muhammadiyah Disaster Management Center) juga melakukan penanggulangan bencana selaras dengan Hyogo Framework for Action serta membangun basis tangguh bencana melalui komunitas-komunitas 
serta melalui struktur Muhammadiyah

di daerah daerah termasuk Kabupaten

Pamekasan.

Komposisi Struktur Organisasi

Lembaga Penanggulangan Bencana

(LBB) pada tubuh Perserikatan

Muhammadiyah yang selanjutnya

disebut MDMC (Muhammadiyah

Disaster Management

Center)

Kabupaten Pamekasan sebagai berikut:

Ketua : Hendri Masduki, M.Si.

Wakil Ketua : Khairul Jannah, MM.

Sekretaris I : Medliham, S.Pd.I.

Sekretaris II : Mubarok Usman, S.Ak.

Bendahara I : Abdul Aziz, SE., ME.

Bendahara II : Moh. Rasul, SE.

Psikolog : Sofi Diantini, S.Psi.

Konselor : Andry Budianto, M.Pd.

: Sirajul Munir, S.Pd.

Anggota dan Tim SAR :

1. Lasan Masduki, S.H.I., M.Hes.

2. Qaiyim Asy'ari, SE., MM.

3. Fadhali Rahman, SE., MM.

4. Mohammad Holis, S.Pd., M.Pd.

5. Mufti Syaifuddin, S.Sos., M.Si.

6. Mohammad Muchlis, S.Pd., M.Pd.

7. Mohammad Sholihin, S.Pd., M.Pd.

8. Zainal Arifin, S.Pd.I., M.Pd.

9. Ahmad Halif Mardian, S.KM.

10. Syaiful Anwar, S.Ak.

11.M. Syamsul Arifin,SE.I.

12.Moh. Iqbal Firdaus, SE.

13.Abdul Mukti, S.IKom.

14.Karman

15.Abd. Hafidz

16.Abdul Halim

17.Sumarna

18. Fauzi Awi Wijaya

19. Nanang Wildan

20.Imam Subahriyanto
21.Riban, SE.

22.Moh. Ruslan, SE.

23. Sofwan Fuad, SE.

24.Tausiburrahman, SE.

25.Moh. Fadil, SE.I.

26. Nuzul Azmi

27.Firman Firdaus

28.Alief Raviananda Hidayat

29.Moh. Ali Nizar

30.Nawafil Hosen

Secara umum maksud dan tujuan

Pendirian Lembaga penanggulangan bencana (LBB) Muhammadiyah Disaster

Management Center (MDMC)

Kabupaten Pamekasan adalah untuk ikut serta di dalam usaha mengembangkan dan menjalankan syi'ar islam, serta menunjang program pemerintah khususnya dalam penanggulangan bencana dan kegiatan sosial lainnya.

Tujuan khusus di dirikannya Muhammadiyah Disaster Manajement Center (MDMC) Kabupaten Pamekasan adalah :

1. Menjadi lembaga legal formal sebagai mitera pemerintah yang berpatisipasi aktif, tanggap, sigap, responsif, dan kredibel dalam hal penanggulangan bencana baik dalam tataran internasional, nasional, maupun regional khusunya dalam gugus cluster se-Madura Raya dan utamnya di Kabupaten Pamekasan sebagai Kabupaten dengan icon Gerbang Salam (Gerakan pembangunan masyarakat Islami). 
2. Meningkatkan dan mengoptimalkan sistem penanggulangan bencana dalam bentuk jejaring simpul-simpul tanggap darurat, rehabilitasi bencana di lingkungan Muhammadiyah dalam penanggulangan bencana; peningkatan kapasitas kader, relawan dan pengelola penanggulangan bencana.

3. Mengembangkan kesadaran bencana di lingkungan Muhammadiyah, kampanye kesadaran menghadapi bencana di masyarakat, advokasi sistem penanggulangan bencana dan usaha-usaha lain dalam program rehabilitasi pasca tanggap darurat yang tersistem dengan program dan prinsip-prinsip gerakan Muhammadiyah.

4. Meningkatkan keterpaduan dan kesiapan AUMKESOS dan Rumah Sakit (Klinik) dalam penanggulangan bencana, peningkatan kualitas manajemen dan pengadaan logistik tanggap darurat, serta advokasi rehabilitasi pasca bencana.

5. Menyelenggarakan Sekolah Siaga Bencana, Relawan Siaga Bencana.

6. Mengadakan Pelatihan dan mobilisasi Tim DMC, Tim SAR, Tim Risiko Sosial.

7. Menghimpun bantuan bencana dan menyalurkannya kepada masyarakat sasaran.
Secara operasional Muhammadiyah Disaster Management Center (MDMC) Kabupaten Pamekasan senantiasa menjalin kerjasama dengan lembaga, organisasi, dan instansi terkait baik internal maupun eksternal

Muhammadiyah sebagai berikut:

1. Lembaga Amil Zakat Infaq dan Shadaqah Muhammadiyah (LAZISMU) Baik Pusat maupun daerah

2. Majelis Pembinaan Kesehatan Umum (MPKU) Muhammadiyah Kabupaten Pamekasan

3. Forum komunikasi Pimpinan Kabupaten (Forkopimka) Pamekasan

4. Instansi terkait dilingkungan Pemeritah Kabupaten Pamekasan

5. Rumah sakit, Puskesmas dan Klinik se-Kabupaten Pamekasan

6. Perguruan Tinggi se-Madura Raya khusunya Perguruan Tinggi Negeri dan Swasta di Kabupaten Pamekasan

7. Organisasi kemahasiwaan seKabupaten Pamekasan

8. SMA/SMK Negeri dan Swasta Se Kabupaten Pamekasan

9. Palang Merah Indoesia (PMI)

10.Instansi dan organisasi terkit yang relevan yang bisa dijadikan mitera.

Hasil penelitian menunjukkan bahwa Kualitas Pelayanan pembinaan penanggulangan bencana mempunyai pengaruh terhadap keputusan satuan 
pendidikan dalam menggunakan jasa konseling pada Muhammadiyah Disaster Management Center (MDMC) Kabupaten Pamekasan. Hal ini sebagaimana hasil perhitungan analisis regresi linier berganda dengan menggunakan alat bantu sofware SPSS for windows 17.00 diperoleh persamaan sebagai berikut:

$\mathrm{Y}=\mathrm{a}+\mathrm{b}_{1} \mathrm{x}_{1}+\mathrm{b}_{2} \mathrm{x}_{2}+\mathrm{b}_{3} \mathrm{x}_{3}+\mathrm{b}_{4} \mathrm{x}_{4}+\mathrm{b}_{5} \mathrm{x}_{5}$

$\mathrm{Y}=0,671+0,288 \mathrm{x}_{1}+0,239 \mathrm{x}_{2}-0,015 \mathrm{x}_{3}+$ $0,187 \mathrm{x}_{4}+0,294 \mathrm{x}_{5}$

$\mathrm{a}=0,671$ menunjukkan konstanta, apabila nilai variabel Kualiatas Pelayanan Pembinaan penanggulangan bencana (X) yang terdiri dari Reliability $\mathrm{X}_{1}$, Responsiveness $\mathrm{X}_{2}$, Assurance $\mathrm{X}_{3}$, Empaty $\mathrm{X}_{4}$, dan Tangible $\mathrm{X}_{5}$, berada pada kondisi awal (konstan) yang mana hal ini di asumsikan sama dengan 0 (nol) maka nilai variabel Keputusan Satuan Pendidikan dalam menggunakan jasa konseling (Y) pada Muhammadiyah Disaster manajemen center (MDMC) Kabupaten Pamekasan sebesar 0,671 .

$\mathrm{b}_{1} \mathrm{x}_{1}=0,288$ menunjukkan besarnya koefisien regresi variabel bebas Reliability $\left(\mathrm{X}_{1}\right)$, yang berarti setiap peningkatan variabel Reliability $\left(\mathrm{X}_{1}\right)$ yang berupa pelayanan yang akurat, ketepatan waktu dalam pelayanan, kesesuaian pelayanan dengan yang di janjikan, penjelasan tentang pelayanan, dan pelayanan yang meyakinkan, dengan anggapan bahwa variabel bebas lainnya $\left(\mathrm{X}_{2}, \mathrm{X}_{3}, \mathrm{X}_{4}, \mathrm{X}_{5}\right)$ konstan, maka nilai variabel Keputusan (Y) akan meningkat sebesar 0,288 atau sebesar 28,8\%. Makna dari penjelasan tersebut adalah apabila variabel Reliability $\left(\mathrm{X}_{1}\right)$ ada kecenderungan meningkat, maka variabel Keputusan Satuan pendidikan (Y) juga meningkat. Dengan demikian Reliability $\quad\left(\mathrm{X}_{1}\right) \quad$ mempunyai pengaruh terhadap Keputusan Satuan Pendidikan dalam menggunakan jasa konseling (Y) pada Muhammadiyah Disaster manajemen center (MDMC) Kabupaten Pamekasan.

$\mathrm{b}_{2} \mathrm{x}_{2}=0,239$ adalah menunjukkan besarnya koefisien regresi variabel bebas Responsiveness ( $\left.\mathrm{X}_{2}\right)$, yang berarti setiap peningkatan variabel Responsiveness $\left(\mathrm{X}_{2}\right)$ berupa sigap dalam menjelaskan varian pelayanan yang ditawarkan, sigap menjawab pertanyaan Satuan pendidikan, respon terhadap keinginan Satuan pendidikan, tepat dalam 
memberikan pelayanan, cepat dalam memberikan pelayanan, dengan anggapan bahwa variabel bebas lainnya $\left(\mathrm{X}_{1}, \mathrm{X}_{3}, \mathrm{X}_{4}, \mathrm{X}_{5}\right)$ konstan, maka nilai variabel Keputusan (Y) meningkat sebesar 0,239 atau sebesar 23,9\%. Makna dari penjelasan tersebut adalah apabila variabel Responsiveness $\left(\mathrm{X}_{2}\right)$ ada kecenderungan meningkat, maka variabel Keputusan Satuan pendidikan (Y) juga meningkat. Dengan demikian Responsiveness $\left(\mathrm{X}_{2}\right)$ mempunyai pengaruh terhadap Keputusan Satuan Pendidikan dalam menggunakan jasa konseling (Y) pada Muhammadiyah Disaster manajemen center (MDMC) Kabupaten Pamekasan.

$\mathrm{b}_{3} \mathrm{X}_{3}=-0,015$ menunjukkan besarnya koefisien regresi variabel bebas Assurance $\left(\mathrm{X}_{3}\right)$ yang berarti setiap peningkatan variabel Assurance $\left(\mathrm{X}_{3}\right)$ berupa menjamin kualitas pelayanan, memberikan rasa aman tentang pelayanan, menjamin Satuan pendidikan bisa mendapatkan pelayanan prima, menjamin Satuan pendidikan untuk mendapatkan arahan, menjamin Satuan pendidikan mendapatkan pelayanan yang di inginkan, dengan anggapan bahwa variabel bebas lainnya $\left(\mathrm{X}_{1}, \mathrm{X}_{2}, \mathrm{X}_{4}\right.$, $\mathrm{X}_{5}$ ) konstan, maka nilai variabel keputusan (Y) meningkat sebesar 0,015 atau sebesar 01,5\%. Makna dari penjelasan tersebut adalah apabila variabel Assurance $\left(\mathrm{X}_{3}\right)$ ada kecenderungan meningkat, maka variabel Keputusan Satuan pendidikan (Y) juga meningkat. Dengan demikian Assurance $\left(\mathrm{X}_{3}\right)$ mempunyai pengaruh terhadap Keputusan Satuan Pendidikan dalam menggunakan jasa konseling (Y) pada Muhammadiyah Disaster manajemen center (MDMC)

Kabupaten Pamekasan.

$\mathrm{b}_{4} \mathrm{X}_{4}=0,187$ menunjukkan besarnya koefisien regresi variabel bebas Empaty $\left(\mathrm{X}_{4}\right)$, yang berarti setiap peningkatan variabel Empaty $\left(\mathrm{X}_{4}\right)$ berupa fokus pada permintaan Satuan pendidikan dalam pelayanan, ketelatenan dalam pelayanan, ketelitian dalam pelayanan, keramahan dalam pelayanan, kemudahan dalam pelayanan, dengan anggapan bahwa variabel bebas lainnya $\left(\mathrm{X}_{1}\right.$, $\left.\mathrm{X}_{2}, \mathrm{X}_{3}, \mathrm{X}_{5}\right)$ konstan, maka nilai variabel Keputusan (Y) akan meningkat sebesar 0,187 atau sebesar 18,7\%. Makna dari penjelasan tersebut adalah apabila 
variabel Empaty $\left(\mathrm{X}_{4}\right)$ ada kecenderungan meningkat, maka variabel Keputusan Satuan pendidikan (Y) juga meningkat. Dengan demikian Empaty $\left(\mathrm{X}_{4}\right)$ mempunyai pengaruh terhadap Keputusan Satuan Pendidikan dalam menggunakan jasa konseling (Y) pada

Muhammadiyah Disaster manajemen center (MDMC)

Kabupaten Pamekasan.

$\mathrm{b}_{5} \mathrm{X}_{5}=0,294$ menunjukkan besarnya koefisien regresi variabel bebas Tangible $\left(\mathrm{X}_{5}\right)$, yang berarti setiap peningkatan variabel Tangible $\left(\mathrm{X}_{5}\right)$ berupa kenyamanan ruang tempat pelayanan, kebersihan ruang tempat pelayanan, penampilan fisik kantor, kerapian tata ruang kantor, kantor pelayanan yang strategis, dengan anggapan bahwa variabel bebas lainnya $\left(\mathrm{X}_{1}, \mathrm{X}_{2}, \mathrm{X}_{3}\right.$, $\mathrm{X}_{4}$ ) konstan, maka nilai variabel Keputusan (Y) akan meningkat sebesar 0,294 atau sebesar 29,4\%. Makna dari penjelasan tersebut adalah apabila variabel Tangible $\left(\mathrm{X}_{5}\right)$ ada kecenderungan meningkat, maka variabel Keputusan Satuan pendidikan (Y) juga meningkat. Dengan demikian Tangible $\quad\left(\mathrm{X}_{5}\right) \quad$ mempunyai pengaruh terhadap Keputusan
Satuan Pendidikan dalam menggunakan jasa konseling (Y) pada Muhammadiyah Disaster manajemen center $(M D M C)$

Kabupaten Pamekasan.

Koefisien determinasi $\quad \mathrm{R}^{2}$ merupakan proporsi yang menjelaskan adanya pengaruh variabel bebas (independent variable) terhadap variabel terikat (dependent variable). Hasil perhitungan $r$ dan $R$ Squere dalam penelitian ini sebagaimana disajikan pada tabel berikut :

Tabel 1

Hasil Perhitungan $r$ dan $R$ Squere

\begin{tabular}{cccc}
\hline Model & $\mathbf{r}$ & $\begin{array}{c}\mathbf{R} \\
\text { Square }\end{array}$ & $\begin{array}{c}\text { Adjusted } \\
\text { R Square }\end{array}$ \\
\hline \multirow{1}{*}{$\mathbf{1}$} & $.759 \mathrm{a}$ & .631 & .628 \\
\hline
\end{tabular}

Sumber: Data yang diolah kembali 2020

Dari hasil perhitungan $r$ dan $R$ square pada tabel 1 di atas, memberikan informasi tentang hubungan atau korelasi antara variabel Kualitas pelayanan pembinaan penanggulangan bencana (X) dengan variabel Keputusan Satuan Pendidikan dalam menggunakan jasa konseling pada Muhammadiyah Disaster Manajement Center (MDMC) Kabupaten Pamekasan dapat dijelaskan bahwa Nilai $\mathrm{r}$ atau multiple $\mathrm{R}$ sebesar 0,759 atau 75,9\% yaitu menggambarkan hubungan antara variabel bebas dengan 
variabel terikat bersifat searah dan kuat sebesar 75,9\%. Sedangkan nilai $\mathrm{R}$ squared atau determinan $\left(\mathrm{R}^{2}\right)$ sebesar 0,631 atau $63,1 \%$, sedangkan sisanyanya sebesar $26,9 \%$ dipengaruhi oleh variabel lain yang tidak termasuk dalam penelitian ini.

Hasil uji hipotesis yang menunjukkan taraf signifikansi adanya pengaruh Kualitas Pelayanan (X) terhadap Keputusan (Y) yang terdiri dari uji hipotesis simultan $\left(\mathrm{F}_{-}\right.$tes $)$dan uji hipotesis parsial ( $\mathrm{t}_{\text {ttes}}$ ).

1. Hipotesis Simultan $\left(\mathrm{F}_{\text {ttes }}\right)$

Hasil uji hipotesis secara bersamasama (simultan) dalam penelitian ini sebagaimana pada tabel berikut:

\section{Tabel 2}

Hasil Uji Hipotesis Simultan (F_tes)

\begin{tabular}{cccc}
\hline $\begin{array}{c}\text { Koefisien } \\
\text { Regresi }\end{array}$ & $\mathbf{F}_{-}$hitung & $\begin{array}{c}\mathbf{F}_{-} \\
\text {hitung }\end{array}$ & $\begin{array}{c}\text { Taraf } \\
\text { nyata } \\
(\mathbf{\alpha})\end{array}$ \\
\hline $\mathrm{X}$ & 65,722 & 1,69 & 0,05
\end{tabular}

Keterangan : Signifikan

Sumber: Data yang diolah kembali 2020

Dari tabel 2 di atas dapat dijelaskan bahwa untuk uji hipotesis simultan dan atau uji $\mathrm{F}$ (F_tes) didapatkan hasil F_hitung sebesar 65,772, sedangkan $\mathrm{F}_{\text {_tabel }}$ sebesar 1,69. Uji simultan dan atau uji $\mathrm{F}$ ( $\left.\mathrm{F}_{\text {tes }}\right)$ dilakukan dengan membandingkan $\mathrm{F}_{\text {_hitung }}$ dengan $\mathrm{F}_{\text {_tabel }}$ pada taraf nyata $\alpha=0,05$.

Dengan demikian dalam pengujian hipotesis simultan dapat dikatakan bahwa Kualitas Pelayanan Pembinaan Penanggulangan bencana yang terdiri dari Reliability $X_{1}$, Responsiveness $X_{2}$, Assurance $X_{3}$, Empaty $X_{4}$, dan Tangible $X_{5}$, secara bersama-sama (simultan) berpengaruh terhadap Keputusan Satuan pendidikan dalam menggunakan jasa konseling (Y) pada Muhammadiyah Disaster Manajement Center (MDMC) Kabupaten Pamekasan.

\section{Hipotesis Parsial ( $\mathrm{t}_{-}$tes $)$}

Hasil uji hipotesis secara sendirisendiri (parsial) dalam penelitian ini sebagaimana pada tabel berikut:

Tabel 3

Hasil Uji Hipotesis Simultan (F_tes)

\begin{tabular}{cccc}
\hline $\begin{array}{c}\text { Koefisien } \\
\text { Regresi }\end{array}$ & $\mathbf{t}_{\text {_hitung }}$ & $\mathbf{t}_{\text {_tabel }}$ & $\begin{array}{c}\text { Taraf } \\
\text { nyata } \\
\text { (a) }\end{array}$ \\
\hline $\mathbf{X}_{1}$ & 2,330 & 1,684 & 0,05 \\
$\mathbf{X}_{2}$ & 2,255 & 1,684 & 0,05 \\
$\mathbf{X}_{3}$ & 2,071 & 1,684 & 0,05 \\
$\mathbf{X}_{4}$ & 1,947 & 1,684 & 0,05 \\
$\mathbf{X}_{5}$ & 3,047 & 1,684 & 0,05
\end{tabular}

Keterangan : Signifikan

Sumber: Data yang diolah kembali 2020

Dari tabel 3 di atas, untuk uji parsial dapat dijelaskan sebagai berikut:

1. Reliability $\mathrm{X}_{1}$ mempunyai nilai $\mathrm{t}_{\text {_hitung }}$ sebesar 2,330, lebih besar dibandingkan dengan nilai $t_{-}$tabel sebesar 1,684. Hal ini dapat maknai bahwa variabel Reliability $X_{1}$ mempunyai pengaruh signifikan (berarti) terhadap Keputusan Satuan 
Pendidikan dalam menggunakan jasa konseling (Y) pada Muhammadiyah Disaster Manajement Center (MDMC) Kabupaten Pamekasan.

2. Responsiveness $\mathrm{X}_{2}$ mempunyai nilai t_hitung sebesar 2,255, lebih besar dibandingkan dengan nilai $t_{-}$tabel sebesar 1,684. Hal ini dapat dimaknai bahwa Responsiveness $\mathrm{X}_{2}$ mempunyai pengaruh signifikan (berarti) terhadap Keputusan Satuan Pendidikan dalam menggunakan jasa konseling (Y) pada Muhammadiyah Disaster Manajement Center (MDMC) Kabupaten Pamekasan.

3. Assurance $\mathrm{X}_{3}$ mempunyai nilai t_hitung sebesar 2,071, lebih besar dibandingkan dengan nilai $\mathrm{t}_{-}$tabel sebesar 1,684. Hal ini dapat dimaknai bahwa Assurance $\mathrm{X}_{3}$ mempunyai pengaruh signifikan (berarti) terhadap Keputusan Satuan Pendidikan dalam menggunakan jasa konseling (Y) pada Muhammadiyah Disaster Manajement Center (MDMC) Kabupaten Pamekasan.

4. Empaty $\mathrm{X}_{4}$ mempunyai nilai t_hitung sebesar 1,947, lebih besar dibandingkan dengan nilai $t_{-t a b e l}$ sebesar 1,684. Hal ini dapat dimaknai bahwa Empaty $\mathrm{X}_{4}$ mempunyai pengaruh signifikan (berarti) terhadap Keputusan Satuan Pendidikan dalam menggunakan jasa konseling (Y) pada Muhammadiyah Disaster Manajement Center (MDMC) Kabupaten Pamekasan.

5. Tangible $\mathrm{X}_{5}$ mempunyai nilai $\mathrm{t}_{-}$hitung sebesar 3,047, lebih besar dibandingkan dengan nilai $\mathrm{t}_{-}$tabel sebesar 1,684. Hal ini dapat dimaknai bahwa Tangible $\mathrm{X}_{5}$ mempunyai pengaruh signifikan (berarti) terhadap Keputusan Satuan Pendidikan dalam menggunakan jasa konseling ( $\mathrm{Y}$ ) pada Muhammadiyah Disaster Manajement Center (MDMC) Kabupaten Pamekasan.

Berdasarkan uji hipotesis parsial dengan menggunakan uji $t$ ( $\left.t_{-t e s}\right)$ dapat dijelaskan bahwa variabel Tangible $\mathrm{X}_{5}$ mempunyai nilai t_hitung yang paling besar (dominan) jika dibandingkan dengan nilai $\mathrm{t}_{\text {_hitung }}$ variabel lainnya $\left(\mathrm{X}_{1}\right.$, $\mathrm{X}_{2}, \mathrm{X}_{3}$, dan $\mathrm{X}_{4}$ ).

Dengan demikian uji hipotesis parsial dalam penelitian ini berbunyi: Tangible $\mathrm{X}_{5}$ yang berhubungan dengan Penampilan fisik tempat pelayanan mempunyai pengaruh signifikan dan paling besar (dominan) terhadap variabel Y yaitu Keputusan Satuan Pendidikan dalam menggunakan jasa konseling pada Muhammadiyah Disaster Manajement Center (MDMC) Kabupaten Pamekasan. 


\section{SIMPULAN}

Kualitas pelayanan pembinaan penanggulangan bencana mempunyai pengaruh yang signifikan terhadap Keputusan Satuan pendidikan dalam menggunakan jasa konseling pada Muhammadiyah Disaster Manajement Center (MDMC) Kabupaten Pamekasan. Hal ini dapat dimaknai bahwa, program pelayanan pembinaan penanggulangan bencana yang dilakukan oleh Muhammadiyah Disaster Manajement Center (MDMC) Kabupaten Pamekasan dapat dirasakan kemanfaatannya oleh satuan pendidikan sebagai mitera kerjasama dan sasaran penerima manfaat dari program pembinaan yang dilakukan oleh Muhammadiyah Disaster Manajement Center (MDMC) Kabupaten Pamekasan.

Dalam pelaksanaan suatu program, Muhammadiyah Disater Manajement Center (MDMC) Kabupaten Pamekasan senantiasa melakukan kerjasama dengan lembaga terkait utamanya dengan Lembaga amil zakat infaq dan shadaqah Muhammadiyah (LAZISMU) Kabupaten Pamekasan dalam hal penghimpunan biaya operasional dalam penyelenggaraan program kegiatan.

\section{DAFTAR PUSTAKA}

Kotler, Philip. 2002. Manajemen Pemasaran dan Strategi Pemasaran. Prenha Hindu. Jakarta.

2004. Manajemen Pemasaran, Jilid 1 dan 2, terjemahan Teguh Hendra, Ronny Antonius Rusli, Edisi Revisi. Prenha Hindu. Jakarta.

Moenir, H.A.S. 2002. Manajemen Pelayanan Umum di Indonesia, Cetakan III, Bumi Aksara. Jakarta.

Nugroho, J Setiadi. 2010. Perilaku Konsumen. Kencana Prenada media Group. Jakarta.

Peraturan Pemerintah Nomor 21 Tahun 2008 tentang Penyelenggaraan Penanggulangan Bencana

Peraturan pemerintah Nomor 21 tahun 2008 tentang penyelenggaraan penanggulangan bencana

Peraturan pemerintah Nomor 22 tahun 2008 tentang pendanaan dan pengelolaan bantuan bencana

Peraturan pemerintah Nomor 23 tahun 2008 tentang peran serta lembaga internasional dan lembaga asing non pemerintah dalam penanggulangan bencana

Peraturan presiden Nomor 70 tahun 2012 tentang perubahan kedua atas perpres Nomor 54 tahun 2010 tentang pengadaan barang / jasa pemerintah

Peraturan presiden Nomor 08 tahun 2008 tentang badan nasional penanggulangan bencana;

Peraturan presiden Nomor 03 tahun 2007 tentang perubahan atas peraturan presiden nomor 83 tahun 2005 tentang badan 
koordinasi nasional penanganan bencana

Peraturan presiden Nomor 83 tahun 2005 tentang badan koordinasi nasional penanganan bencana

Peraturan gubernur jawa timur nomor 27 tahun 2009 tentang uraian tugas sekretariat, bidang, sub bagian dan seksi badan penanggulangan bencana daerah provinsi jawa timur.

Peraturan Bupati Pamekasan Provinsi Jawa Timur Peraturan Daerah Kabupaten Pamekasan nomor 6 tahun 2al4 tentang penanggulangan bencana.

Simamora, Bilson. 2004, Riset Pemasaran, Falsafah Teori dan Aplikasi. Gramedia Pustaka Utama. Jakarta.

Santoso, Singgih. 2002, Buku Latihan SPSS statistic Parametrik. Alek Media Komputindo. Jakarta.

Sudharmanto. 2005. Analisa Regresi Linear Berganda Dengan SPSS. Liberty. Yogyakarta.

Sugiyono. 2006. Metode Penelitian Administradisi. Alpha Beta. Bandung.

2011. Statistika untuk Penelitian. Alpha Beta. Bandung.

Supranto, J. 1997. Pengukuran Tingkat Kepuasan Pelanggan. Rineka Cipta. Jakarta.

Swastha, Basu D.H, dan Handoko, Hani T. 2000. Manajemen Pemasaran, Analisa Prilaku Konsumen. Edisi Pertama. BPFE. Yogyakarta.

Tjiptono, Fandy. 2003. Strategi Pemasaran. Andy Offset.
Umar, Husein. 2002. Riset Pemasaran dan Perilaku Konsumen. Pustaka Utama. Jakarta.

Undang-undang Nomor 24 tahun 2007 tentang penanggulangan bencana.

\section{Yogyakarta.}

